\title{
ANALISIS KEBIJAKAN DAN STRATEGI PENGENTASAN KEMISKINAN DI KOTA TANGERANG PROVINSI BANTEN
}

\author{
Penulis: Arif Fadilla, SE. MT \\ Tenaga Pengajar Fakultas Ekonomi dan Bisnis \\ Universitas Singaperbangsa Karawang \\ Email: ariffadila@gmail.com
}

\begin{abstract}
ABSTRAK
Kemiskinan biasanya dipandang sebagai suatu keadaan dimana seseorang, keluarga, atau sekelompok masyarakat yang mengalami kekurangan khususnya dalam hal rendahnya kualitas kehidupan sosial-ekonomi yang dialami sehari-hari. Secara konseptual, kemiskinan dapat dijelaskan melalui teori-teori kemiskinan seperti kemiskinan kultural, kemiskinan struktural, dan kemiskinan alamiah. Penelitian ini menggunakan Metode Analisis Deskriptif terhadap Kebijakan dan Strategi Pengentasan Kemiskinan di Kota Tangerang Provinsi Banten dengan menggunakan teori Implementasi Merilee S. Grindle. Penelitian ini menemukan bahwa pelaksanaan kebijakan pengentasan kemiskinan melalui Tim Koordinasi Penanggulangan Kemiskinan (TKPK). TKPK melakukan koordinasi penanggulangan kemiskinan sekaligus mengendalikan pelaksanaan kebijakan dan program penanggulangan kemiskinan secara menyeluruh. Koordinasi penanggulangan kemiskinan dimaksud meliputi: sinkronisasi, harmonisasi, integrasi antar SKPD, institusi baik vertikal maupun horizontal, dan terjalinnya sinergi antara kebijakan pemerintah dengan usulan masyarakat dari bawah. Secara umum penelitian ini menemukan bahwa kebijakan dan strategi pengentasan kemiskinan di Kota Tangerang dapat dikatakan memberikan hasil positif dengan indikator turunnya jumlah masyarakat miskin, meningkatnya Indeks Pembangunan Manusia dan meningkatnya Harapan Hidup masyarakat secara signifikan selama tiga tahun terakhir dari tahun 2012 sampai dengan tahun 2014.
\end{abstract}

Kata Kunci: Kemiskinan, Strategi dan Kebijakan Pengentasan Kemiskinan, TKPK Kota Tangerang

\section{Pendahuluan}

Kemiskinan biasanya dipandang sebagai suatu keadaan dimana seseorang, keluarga, atau sekelompok masyarakat yang mengalami kekurangan khususnya dalam hal rendahnya kualitas kehidupan sosial-ekonomi yang dialami sehari-hari. Secara konseptual, kemiskinan dapat dijelaskan melalui teoriteori kemiskinan seperti kemiskinan kultural, kemiskinan struktural, dan kemiskinan alamiah. Menurut Surbakti (Usman, 2006), kemiskinan kultural bukanlah bawaan melainkan akibat dari tidak kemampuan menghadapi kemiskinan yang berkepanjangan. Soetandyo Wignjosoebroto dalam "Kemiskinan Struktural : Masalah dan Kebijakan" (Suyanto, 1995) mendefinisikan "Kemiskinan struktural merupakan kemiskinan yang disebabkan oleh faktor struktur ekonomi dan politik yang melingkupi si miskin." Struktur ekonomi dan politik yang kurang berpihak pada sekelompok masyarakat tertentu sehingga menimbulkan hambatan-hambatan dalam akses sumber daya ekonomi, lapangan pekerjaan dan partisipasi dalam pembangunan. Sedangkan kemiskinan alamiah terjadi karena ketiadaan atau kelangkaan sumber daya ekonomi, input faktor-faktor produksi yang berupa modal, tanah, sumber daya manusia dalam hal ini tingkat dan kualitas pendidikan maupun kondisi geografis yang terkait dengan tempat tinggal suatu masyarakat.

Definisi kemiskinan menurut Friedman dalam Usman (2006) adalah ketidaksamaan kesempatan untuk mengakumulasikan basis kekuatan sosial. Kemiskinan adalah permasalahan yang sifatnya multidimensional. Pendekatan dengan satu bidang ilmu tertentu tidaklah mencukupi untuk mengurai makna dan fenomena yang menyertainya. Definisi secara umum yang lazim dipakai dalam perhitungan dan kajiankajian akademik adalah pengertian 
kemiskinan yang diperkenalkan oleh Bank Dunia yaitu sebagai ketidakmampuan mencapai standar hidup minimum (Word Bank, 1990).

Lebih lanjut BAPPENAS (2004) mendefinisikan kemiskinan sebagai kondisi dimana seseorang atau sekelompok orang tidak mampu memenuhi hak-hak dasarnya antara lain: pangan, kesehatan, pendidikan, pekerjaan, perumahan, air bersih, pertanahan, sumberdaya alam dan lingkungan hidup, rasa aman dari perlakukan atau ancaman tindak kekerasan dan hak untuk berpartisipasi dalam kehidupan sosial-politik, baik bagi perempuan maupun laki-laki. Untuk mewujudkan hak-hak dasar masyarakat miskin ini, BAPPENAS menggunakan beberapa pendekatan utama yakni; pendekatan kebutuhan dasar (basic needs approach), pendekatan pendapatan (income approach), pendekatan kemampuan dasar (human capability approach) dan pendekatan objective and subjective. Berdasarkan Perpres Nomor 7 Tahun 2005 tentang RPJMN, kemiskinan terjadi ketika seseorang atau sekelompok orang, baik laki-laki dan perempuan, tidak terpenuhi hak-hak dasarnya untuk mempertahankan dan mengembangkan kehidupan yang bermartabat.

Undang-Undang Nomor 25 Tahun 2000 tentang PROPENAS menyebutkan berdasarkan penyebabnya kemiskinan dapat dibedakan menjadi dua, yaitu kemiskinan kronis (chronic poverty) yang disebabkan: (1) sikap dan kebiasaan hidup masyarakat yang tidak produktif; (2) keterbatasan sumber daya dan keterisolasian; dan (3) rendahnya taraf pendidikan dan derajat kesehatan, terbatasnya lapangan kerja, dan ketidakberdayaan masyarakat, dan kemiskinan sementara (transient poverty) yang disebabkan (1) perubahan siklus ekonomi dari kondisi normal menjadi krisis ekonomi; (2) perubahan yang bersifat musiman seperti kasus kemiskinan nelayan dan pertanian tanaman pangan; dan (3) bencana alam atau dampak dari suatu kebijakan.

Sedangkan metode yang digunakan Badan Pusat Statistik (BPS) untuk menghitung penduduk miskin adalah metode Head Count Index. Menurut metode ini, penduduk miskin adalah penduduk yang berada di bawah suatu batas, yang disebut garis kemiskinan. Dimana Garis Kmisknan didefinisikan sebagai nilai rupiah yang harus dikeluarkan seseorang dalam memenuhi kebutuhan hidup minimumnya, baik itu kebutuhan hidup minimum makanan (beras, umbi-umbian, ikan dan sebagainya) maupun kebutuhan hidup minimum bukan makanan (perumahan, kesehatan, pendidikan, transportasi, dan sebagainya terdiri dari 2 komponen, yaitu garis kemiskinan makanan (food line) dan garis kemiskinan non-makanan (non food line). Agar seseorang dapat dikatakan hidup layak, pemenuhan akan kebutuhan makanan saja tidak cukup. Oleh karena itu perlu juga dipenuhi kebutuhan dasar bukan makanan, seperti perumahan, pendidikan, kesehatan, pakaian, serta aneka barang dan jasa lainnya. Batas kebutuhan minimum untuk makanan ditambah kebutuhan minimum untuk bukan makanan itulah yang disebut Garis Kemiskinan. Ringkasnya, garis kemiskinan terdiri atas dua komponen, yaitu garis kemiskinan makanan dan garis kemiskinan bukan makanan.

Dalam rangka mendukung penetapan sasaran program perlindungan sosial dan mengacu pada Peraturan Presiden Nomor 15 Tahun 2010 tentang Percepatan Pengentasan Kemiskinan, Inpres Nomor 1 Tahun 2010 tentang Percepatan Pelaksanaan Prioritas Pembangunan Nasional Tahun 2010, dan Inpres No 3 Tahun 2010 tentang Program Pembangunan Yang Berkeadilan, TNP2K bekerja sama dengan BPS dan Bank Dunia mencoba mengembangkan suatu sistem penetapan sasaran yang baru yang merupakan kelanjutan dari PSE 2005 dan PPLS 2008. Sistem tersebut diarahkan guna menghasilkan Basis Data Terpadu yang dapat digunakan oleh berbagai program Pengentasan kemiskinan, program jaminan sosial, ataupun program pro-rakyat lainnya yang memiliki target sasaran.

Dalam tahap pengumpulan data, para pencacah mengunjungi ruta/keluarga yang telah terdaftar untuk mengumpulkan informasi mengenai karakteristik demografi dan sosial ekonomi seperti komposisi ruta, pendidikan, pekerjaan, kualitas perumahan, sanitasi, kepemilikan aset, dan akses terhadap bantuan/jaminan sosial dengan menggunakan kuesioner (PPLS 2011. RT). Kriteria pemilihan variabel kuesioner termasuk:

1. Prediktor kemiskinan terbaik;

2. Ketersediaan sumber data yang ada, terutama Susenas;

3. Mudah diamati oleh enumerator saat melakukan penilaian ruta/keluarga;

4. Tidak mudah untuk dimanipulasi dalam jangka pendek oleh ruta/keluarga. 
Rumah tangga dalam Basis Data Terpadu dapat dikelompokkan ke dalam kelompok yang disebut desil. Desil adalah kelompok per-sepuluhan sehingga seluruh rumah tangga dapat dibagi ke dalam 10 desil. Dengan demikian pengelompokan rumah tangga dalam Basis Data Terpadu adalah sebagai berikut:

1. Desil 1 adalah rumah tangga dalam kelompok $10 \%$ terendah

2. Desil 2 adalah rumah tangga dalam kelompok antara 10-20\% terendah

3. Desil 3 adalah rumah tangga dalam kelompok antara 20-30\% terendah dan seterusnya

4. Desil 10 adalah rumah tangga dalam kelompok $10 \%$ dengan tingkat kesejahteraan paling tinggi.

Basis Data Terpadu berisikan kelompok Desil 1, Desil 2, Desil 3 dan Desil 4 karena memuat $40 \%$ rumah tangga dengan peringat kesejahteraan terendah. Pada update PPLS tahun 2011 cakupannya diperluas dengan menghasilkan 4 (empat) kategori miskin antara lain :

$\begin{array}{lrr}\text { 1. Kelompok } & \text { Sangat } & \text { Miskin atau } \\ \text { penduduk } & \text { yang } & \text { rata-rata }\end{array}$

\section{Metode Analisis}

Penelitian ini menggunakan Metode Analisis Deskriptif terhadap kebijakan dan strategi Pengentasan. Fokus penelitian ini adalah (1) Pelaksanaan kebijakan dan strategi Pengentasan kemiskinan (2) faktor- faktor yang mempengaruhi pelaksanaan kebijakan dan strategi Pengentasan kemiskinan (3) Interaksi kepentingan aktor yang terlibat dalam pelaksanaan kebijakan dan strategi Pengentasan kemiskinan. Unit analisis yang digunakan pada penelitian ini adalah Bappeda dan SKPD terkait dengan Pengentasan kemiskinan di Kota Tangerang. Data yang diperoleh dari data primer dan sekunder. Pengumpulan data dilakukan melalui observasi, dokumentasi, dan wawancara mendalam. Sedangkan teori yang digunakan dalam penelitian ini menggunakan teori Implementasi Merilee S. Grindle karena relevan dengan penelitian mengenai analisis kebijakan publik.

Keberhasilan Implementasi menurut Merilee S. Grindle dipengaruhi oleh dua variabel besar, yakni isi kebijakan (content of policy) dan lingkungan implementasi (context of implementation). Variabel isi kebijakan ini pengeluarannya dibawah 0,8 kali garis Kemiskinan, kelompok miskin yaitu penduduk yang pengeluarannya dibawah garis kemiskinan

2. Kelompok Miskin atau penduduk yang rata-rata pengeluarannya dibawah 0,8 kali garis Kemiskinan, kelompok miskin yaitu penduduk yang pengeluarannya dibawah garis kemiskinan

3. Kelompok Hampir Miskin yaitu penduduk yang pengeluarannya diatas garis kemiskinan tetapi dibawah 1,2 kali garis kemiskinan

4. Kelompok Rentan Miskin yaitu penduduk dengan rata-rata pengeluaran dibawah 1,7 kali garis kemiskinan tetapi diatas 1,2 kali garis kemiskinan

Perbedaan antara PPLS 2011 dengan PPLS 2008 adalah tidak adanya kelompok rentan miskin pada PPLS 2008 jadi kalaupun PPLS 2011 jumlahnya lebih banyak karena di dalamnya memasukkan kelompok rentan miskin.

mencakup : Pertama, sejauhmana kepentingan kelompok sasaran atau target groups termuat dalam isi kebijakan. Dalam hal ini masyarakat miskin beraspirasi dan mengadukan keluhannya kepada Ketua RT setelah itu aspirasi masyarakat itu dibawa Ketua RT di dalam Musrenbang Kelurahan Disini aspirasi masyarakat dikumpulkan dengan membuat daftar rencana kegiatan prioritas. Setelah itu daftar rencana kegiatan prioritas ini dibawa ke tingkat lebih lanjut yaitu Musrenbang Kecamatan, disini aspirasi masyarakat tadi dipilih yang prioritas, dimana di kecamatan melihat masyarakat miskin mana dari berbagai kelurahan yang benar-benar membutuhkan. Selanjutnya dibawa ke tingkat lebih tinggi yaitu musrenbang Kota. Disini aspirasi masyarakat yang prioritas dipilih masing-masing lima dari ketiga bidang, bidang ekonomi, sosial budaya dan infrastruktur. Setelah dipilih dan dikoordinasikan dengan semua pihak yang terkait, maka dari hasil aspirasi skala prioritas tersebut menjadi isi kebijakan Pengentasan kemiskinan. (AG.Subarsono, 2005:93). Kedua, jenis manfaat yang diterima oleh target kelompok masyarakat baik sektoral maupun regional. Ketiga sejauhmana tercapainya perubahan atau peningkatan yang diinginkan dari sebuah kebijakan. 


\section{Komposisi Demografi dan Kemiskinan di Kota Tangerang}

Kota Tangerang secara resmi dibentuk pada tanggal 28 Februari tahun 1993 melalui penetapan Undang-undang Nomor 2 Tahun 1993 tentang Pembentukan Kotamadya Daerah Tingkat II Tangerang. Sebelumnya Kota ini merupakan bagian dari wilayah Kabupaten Tangerang, kemudian ditingkatkan statusnya menjadi kota administratif, dan akhirnya ditetapkan sebagai kotamadya pada tanggal 28 Februari 1993.

Jumlah Penduduk Kota Tangerang pada tahun 2015 adalah sebanyak 1.999 .894 jiwa, atau mengalami peningkatan dari tahun 2013 sebanyak 1.952.396 jiwa, dan 1.798.601 jiwa pada tahun 2010. Laju pertumbuhan penduduk rata-rata pada periode tahun 20002010 sebesar 3,04 persen per tahun, sedangkan pada tahun 2011-2015 sebesar 3,09 persen pertahun. Lihat gambar dihalaman selanjutnya.

Gambar 1. Perkembangan Jumlah dan Laju Pertumbuhan Penduduk Kota Tangerang Tahun 2011-2015

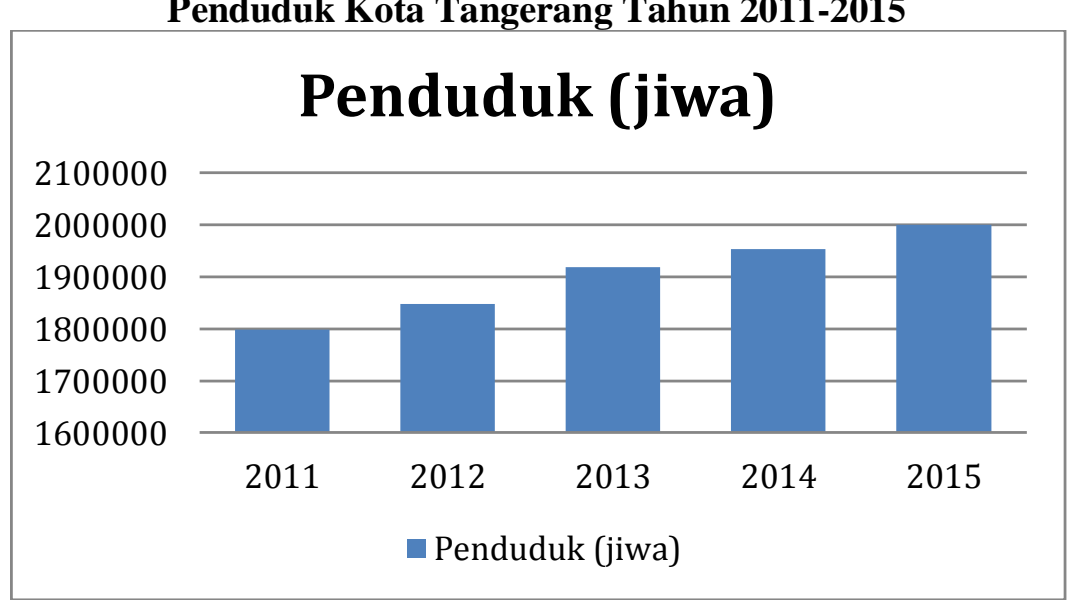

Sumber: Diolah dari Kota Tangerang Dalam Angka, 2015

Produk Domestik Regional Bruto (PDRB) menggambarkan laju pertumbuhan ekonomi negara, provinsi, kota dan kabupaten dalam periode tertentu. Makin besar pertumbuhan PDRB-nya maka diasumsikan makin baik pula perkembangan ekonomi suatu wilayah dan semakin sejahtera di daerah tersebut. Masalah yang mendasar bukan bagaimana

meningkatkan PDRB, tetapi siapa yang menumbuhkan/ meningkatkan PDRB, sebagian besar masyarakat atau hanya beberapa gelintir saja. Dengan demikian tentu saja peningkatan PDRB tidak selalu berkorelasi dengan penurunan jumlah penduduk miskin, sebagaimana akan ditunjukan pada Tabel 2.

Tabel 1.

Perkembangan Produk Domestik Regional Bruto (PDRB) Kota Tangerang (milyar)

\begin{tabular}{|l|r|r|r|}
\hline \multicolumn{1}{|c|}{ LAPANGAN USAHA } & $\mathbf{2 0 1 2}$ & $\mathbf{2 0 1 3}$ & $\mathbf{2 0 1 4}$ \\
\hline 1. PERTANIAN & $1.127,54$ & $1.279,98$ & $1.501,16$ \\
\hline 2. PERTAMBANGAN DAN PENGGALIAN & 0,00 & 0,00 & 0,00 \\
\hline 3. INDUSTRI PENGOLAHAN & $32.911,01$ & $36.222,90$ & $38.124,91$ \\
\hline 4. LISTRIK, GAS DAN AIR BERSIH & 140,20 & 164,47 & 214,65 \\
\hline 5. BANGUNAN & $5.252,21$ & $6.235,00$ & $7.826,89$ \\
\hline 6. PERDAGANGAN, HOTEL DAN RESTORAN & $10.737,81$ & $11.504,17$ & $12.427,35$ \\
\hline 7. PENGANGKUTAN DAN KOMUNIKASI & $15.840,05$ & $19.596,98$ & $28.483,33$ \\
\hline 8. KEUANGAN & $1.040,91$ & $1.111,68$ & $1.350,93$ \\
\hline 9. JASA-JASA & $1.038,51$ & $1.211,38$ & $1.542,67$ \\
\hline PRODUK DOMESTIK REGIONAL BRUTO & $\mathbf{8 3 . 6 4 8 , 1 3}$ & $\mathbf{9 4 . 2 4 1 , 1 9}$ & $\mathbf{1 1 0 . 9 2 2 , 5 3}$ \\
\hline
\end{tabular}

Sumber: Kota Tangerang Dalam Angka Tahun 2015

Jika yang berperan menumbuhkan PDRB hanya pengusaha kaya yang jumlahnya sedikit, maka manfaat dari pertumbuhan itupun hanya dapat dirasakan oleh merekamereka saja, sehingga kemiskinan maupun ketimpangan akan semakin parah. Lain halnya jika pertumbuhan itu dihasilkan oleh orang banyak, maka mereka pula lah yang memperoleh manfaat terbesarnya dan buah dari pertumbuhan ekonomi akan terbagi secara lebih merata.

Gini Ratio tidak dapat menjawab kedua pertanyaan tersebut. Oleh karena itu, Gini Ratio perlu disandingkan dengan indikator 
lain yang telah dikembangkan oleh Bank Dunia dan Lembaga Studi Pembangunan Universitas Sussex untuk memberikan gambaran lebih jelas mengenai masalah ketidakadilan (inequality) melalui indikator yang disebut relative inequality. Relative inequality diartikan sebagai ketimpangan dalam distribusi pendapatan yang diterima oleh berbagai kelas atau kelompok masyarakat. Relative inequality dan absolute poverty merupakan dua aspek kembar keadilan dalam proses pemerataan pembangunan atau pemerataan pendapatan nasional/daerah.

Kriteria Bank Dunia membagi distribusi pendapatan menjadi 3 (tiga) kelompok, yakni 40 persen penduduk berpendapatan rendah (miskin), 40 persen penduduk berpendapatan menengah (kaya) dan 20 persen penduduk berpendapatan tinggi (terkaya). Kriteria relative inequality berdasarkan kriteria Montek S. Ahluwalia atau Bank Dunia memperlihatkan bahwa posisi Kota Tangerang dengan 40 persen penduduk berpendapatan rendah menikmati antara 12-17 persen Produk domestik. Maka tahun 2010 kesenjangan pendapatan bergeser dari kesenjangan pendapatan yang lunak pada tahun 2009 berubah menjadi kesenjangan sedang/moderat pada tahun 2010, dan demikian pula hingga tahun 2012.

Pada gambar 3. di bawah, dapat dibaca arti dari garis lengkung 0B, yaitu $20 \%$ kelompok paling miskin menikmati $8 \%$ pendapatan daerah, kelompok $20 \%$ berikutnya hanya menikmati $12 \%$ pendapatan, sehingga $80 \%$ keluarga hanya menikmati $40 \%$ pendapatan daerah. Dengan demikian ternyata sebagian besar pendapatan daerah $(60 \%)$ dikuasai oleh $20 \%$ kelompok keluarga kaya

Angka Gini Ratio menurut H.T. Oshima dalam Widodo (1990), ketimpangan rendah (low) bila GR kurang dari 0,3; ketimpangan sedang (moderate) bila GR 0,3 sampai dengan 0,4 dan tinggi (high) bila GR lebih dari 0,4. Sedangkan menurut Michael P. Todaro distribusi pendatan relatif merata (ketimpangan rendah) bila GR antara 0,2 sampai dengan 0,35; relatif timpang (ketimpangan sedang) bila GR lebih dari 0,35 dan kurang dari 0,5 dan sangat timpang bila GR antara 0,5 sampai dengan 0,7 . Kalau kita perhatikan nilai rasio gini pada Gambar 3. ketimpangan pendapatan penduduk Kota Tangerang berada pada ketimpangan sedang.

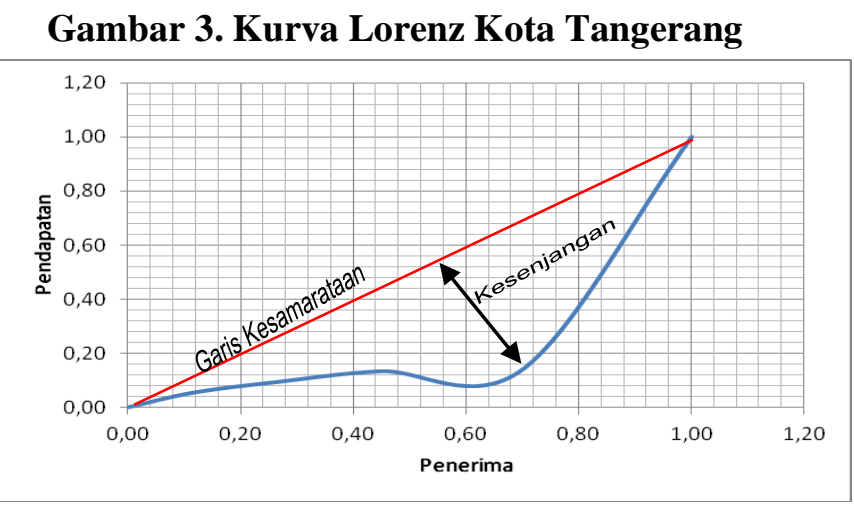

Sumber : Hasil Analisis, 2013

\section{Indeks Pembangunan Manusia (IPM)}

Indeks pembangunan manusia (IPM) pada tahun 2012 mampu mencapai 75,44\% meningkat dari tahun 2010 yang sebesar $75,17 \%$. Angka indeks ini bahkan melebihi dari target pembangunan nasional, dimana IPM 65\%. Secara keseluruhan Indeks Pembangunan Manusia di Kota Tangerang mengalami peningkatan untuk semua indikator. Angka harapan hidup pada tahun 2011 sebesar 68,41 persen mengalami peningkatan menjadi 68,41 persen pada tahun 2012. Kondisi ini melampau target Derajat Kesehatan yang ditetapkan pada tahun 2015 sebesar 67,9 tahun.

Kemudian angka melek huruf pada tahun 2012 di Kota Tangerang telah mencapai $98,43 \%$, hal ini menunjukkan bahwa masih ada sekitar $2,77 \%$ penduduk yang belum bisa menulis dan membaca tulisan Latin di Kota Tangerang. Kondisi IPM Kota Tangerang adalah sebagai berikut: 
Gambar 4. Indeks Pembangunan Manusia

Kota Tangerang Tahun 2010-2012

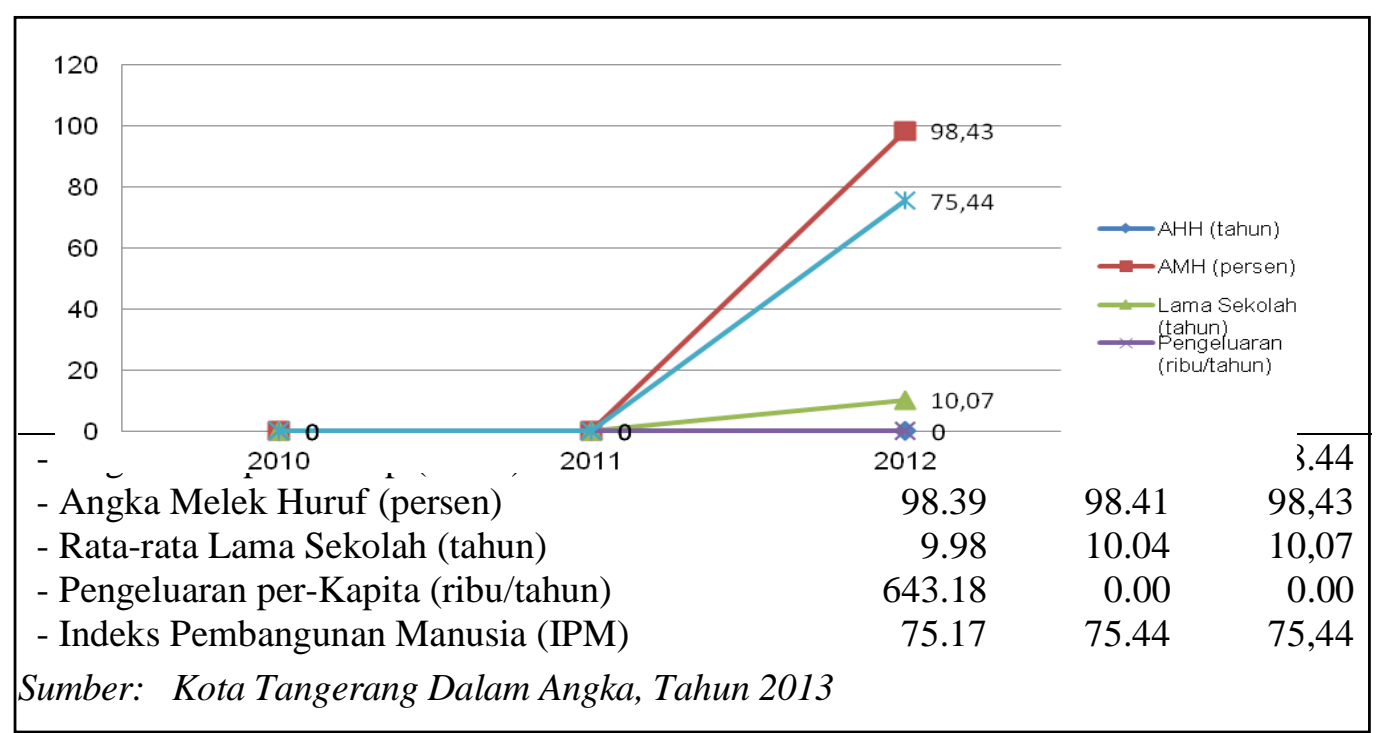

\section{Indeks Kemiskinan Manusia (IKM)}

UNDP mengukur kemiskinan manusia dalam satuan hilangnya tiga hal utama yakni kehidupan (>30 persen penduduk negara-negara yang paling miskin cenderung hidup kurang dari 40 tahun), pendidikan dasar (diukur oleh persentase penduduk dewasa yang buta huruf) dan ketetapan ekonomi (economic provisioning) diukur oleh persentase penduduk yang tidak memiliki akses terhadap pelayanan kesehatan dan air bersih ditambah persentase anak-anak dibawah umur 5 tahun yang kekurangan berat badan). Angka IKM menunjukkan proporsi penduduk yang secara luas

Tabel 3. memperlihatkan bahwa angka IKM Kota Tangerang menunjukkan angka penurunan yaitu dari 10,99 pada tahun 2009 menurun menjadi 9,48 pada tahun 2010. Hal ini menunjukkan perkembangan yang positif dimana hilangnya 3 (tiga) hal utama daya hidup, ilmu pengetahuan dan ketetapan ekonomi semakin berkurang. Penurunan angka IKM ini berlawanan dengan keberadaan penduduk miskin yang justru meningkat pada tahun 2010. Kejadian ini dapat disebabkan oleh salah satu komponen IKM yang tidak berkorelasi secara kuat dengan insiden kemiskinan. Kajian dipengaruhi oleh hilangnya 3 (tiga) hal utama (daya hidup, ilmu pengetahuan dan ketetapan ekonomi).

Angka IKM yang rendah berarti menunjukkan hal yang bagus, yaitu sedikitnya persentase penduduk yang mengalami kehilangan 3 (tiga) hal tersebut. Sementara IKM yang tinggi menunjukkan keadaan sebaliknya karena proporsi kehilangannya lebih besar. Indeks ini berlandaskan pada konsep deprivasi dimana kemiskinan dipandang sebagai akibat tidak tersedianya kesempatan dan pilihan.

kuantitatif terhadap kemiskinan yang dilakukan pada bulan Mei 2005 menemukan bahwa rumah tangga tanpa akses ke air bersih berkorelasi positif tetapi sangat lemah terhadap insiden kemiskinan sedangkan balita dengan status gizi buruk mempunyai hubungan yang positif tapi sedang terhadap insiden kemiskinan. Pada kajian tersebut juga menyebutkan bahwa tingkat kemiskinan memiliki suatu hubungan positif yang kuat dengan keberadaan sektor informal $(\mathrm{r}=0,8$, dimana hubungan dikatakan sebagai sempurna jika $r=1$ ). 
Tabel 2 Indeks Kemiskinan Manusia di Kota Tangerang Tahun 2009 - 2012

\begin{tabular}{|l|c|c|c|c|}
\hline \multicolumn{1}{|c|}{ Uraian Indikator } & $\mathbf{2 0 0 9}$ & $\mathbf{2 0 1 0}$ & $\mathbf{2 0 1 1} * *$ & $\mathbf{2 0 1 2} * *$ \\
\hline $\begin{array}{l}\text { Peluang bayi 0 tahun tidak dapat hidup sampai umur 40 } \\
\text { tahun/Probability at birth of not surviving to age } 40(\%)\end{array}$ & 13,2 & 12,3 & 12,3 & 12,03 \\
\hline Pengetahuan/Knowledge : Angka Buta Huruf (persen) & 1,65 & 1,61 & 1,6 & 1,57 \\
\hline Standar Hidup/A decent standard of living & 11,89 & 8,84 & 7,89 & 6,48 \\
\hline $\begin{array}{l}\text { Persentase rumah tangga yang sumber air minum utama } \\
\text { bukan air bersih }\end{array}$ & 21,88 & 15,78 & 13,86 & 10,72 \\
\hline Persentase balita gizi buruk/balita berat badan kurang)* & 1,89 & 1,9 & 2,09 & 2,24 \\
\hline Indeks Kemiskinan Manusia/Human Poverty Index (HPI) & 10,99 & 9,48 & 9,12 & 8,42 \\
\hline
\end{tabular}

Sumber: BPS Kota Tangerang

*) Profil Kesehatan, Dinas Kesehatan Kota Tangerang

**) Hasil Analisis Prediksi Trend, 2013

Apabila diperhatikan masing-masing indikator pembentuk indeks komposit IKM nampaknya standar hidup layak masyarakat yang diukur melalui tiga jenis variabel masih relatif rendah. Diperlihatkan dengan masih tingginya persentase penduduk yang berusia pendek yang meninggal sebelum usia 40 tahun sebesar 12,03 persen, banyaknya penduduk yang belum memiliki akses ke fasilitas air bersih sebesar 10,72 persen.

Namun demikian apabila dilihat komponen pembentuk IKM dari tahun 2009 dan hasil analisis pada tahun 2012 memperlihatkan perkembangan yang amat menggembirakan. Dari indikator ketetapan ekonomi akses terhadap air minum yang sehat meningkat cukup signifikan dari 78,12 persen pada tahun 2009 meningkat menjadi 89,28 persen pada tahun 2012 . Sedangkan dari aspek kesehatan yaitu peluang bayi umur 0 tahun tidak bisa hidup sampai umur 40 tahun (Persentase penduduk berumur pendek) juga semakin berkurang dari 13,2 persen pada tahun 2009 menjadi 12,03 persen. Hal ini tentu saja karena pengaruh perbaikan pada sektor kesehatan, lingkungan, pemberantasan penyakit menular dan perbaikan gizi. Terlebih lagi, disediakannya fasilitas pengobatan gratis untuk berbagai jenis penyakit oleh Pemda Kota Tangerang bagi keluarga miskin dan rentan miskin sebagai pemegang kartu Multiguna pada tahun 2010 dan kemudian digratiskan pada tahun 2012. Masyarakat yang tidak mampu berobat karena keterbatasan ekonomi, akhirnya dapat tertolong karena adanya fasilitas berobat gratis baik untuk berobat jalan maupun rawat inap.

Hingga tahun 2012 persentase gizi kurang semakin meningkat menjadi 2,24 persen. Walaupun demikian pengaruh gizi buruk terhadap penghitungan nilai IKM di Kota Tangerang tidak berpengaruh secara signifikan karena persentasenya tergolong relatif kecil jika dibandingkan dengan persentase rumah tangga yang sumber air minum utama bukan air bersih mencapai 10,72 persen.

Pada tahun 2012 penanganan balita ini telah mendapat perhatian cukup serius, perilaku hidup sehat dari orang tua ditanamkan pada masyarakat. Data terakhir dari Dinas Kesehatan Kota Tangerang diketahui penanganan gizi balita hingga tahun 2012 sudah dapat mengejar target. Indikator ini dicapai melalui beberapa kegiatan, antara lain penyusunan peta informasi masyarakat kurang gizi, Pemberian Makanan Tambahan (PMT) kepada 336 balita melalui pemberian susu bubuk, pendataan status gizi balita oleh 1.034 kader Posyandu, distribusi kapsul Vitamin A di Posyandu, monitoring dan evaluasi terhadap anak gizi buruk, sosialisasi tanda-tanda anak gizi buruk kepada tokoh-tokoh formal, penyuluhan masa emas dan penyuluhan Kadarzi kepada ibu balita. Cakupan Pemberian Makanan Tambahan pendamping ASI pada anak usia 6-24 bulan keluarga miskin dengan target $100 \%$, didapatkan realisasi sebesar $100 \%$ atau $100 \%$. Indikator ini dicapai melalui kegiatan Pemberian Tambahan Makanan dan Vitamin yang bertujuan untuk meningkatkan status gizi balita.

Dari indikator ilmu pengetahuan, buta huruf yang biasanya disandang oleh orangorang yang tidak berkesempatan menikmati pendidikan karena hidup dibawah tekanan ekonomi juga menunjukkan adanya penurunan dari 1,65 persen pada tahun 2009 menjadi 1,61 
persen pada tahun 2010. Kondisi ini lebih baik lagi pada tahun 2012, dimana Angka melek huruf (AMH) atau kemampuan baca tulis penduduk Kota Tangerang usia 10 tahun ke atas pada tahun 2012 sebesar 98,43 persen, naik dari tahun sebelumnya sebesar 98,41 persen. Demikian pula ratarata lama sekolah yang mencapai 10,07 tahun atau setara kelas 1 SLTA.

Kemampuan suatu wilayah untuk mengelola sumber daya ekonomi yang ada, antara lain tergantung pada kecakapan pengelolaan dan kapabilitas teknik dari penduduknya serta akses terhadap pasar. Tentunya untuk memiliki kecakapan tersebut penduduk dituntut memiliki pendidikan yang memadai yang menjadi dasar pemahaman. Pendidikan yang memadai memiliki peranan penting dalam membentuk kemampuan tiap individu untuk menyerap informasi dalam rangka pengembangan kapasitas dan kapabilitas individu yang bersangkutan. Sehingga diasumsikan semakin tinggi tingkat pendidikan penduduk suatu daerah maka semakin baik pula sumberdaya manusia yang dimiliki daerah tersebut.

Berbagai hasil penelitian juga menunjukan bahwa pendidikan dasar memberikan kontribusi yang paling tinggi diantara semua jenis investasi dan bahkan lebih besar daripada tingkat pengembalian yang dihasilkan dari kebanyakan proyek infrastruktur public.

\section{Analisis Kebijakan dan Strategi Pengentasan Kemiskinan}

Dalam rangka percepatan penurunan angka kemskinan di Kota Tangerang, banyak kebijakan dan program penanggulangan kemiskinan dilaksanakan, baik oleh Pemerintah Pusat, pemerintah Propinsi maupun pemerintah Kota Tangerang. Program penanggulangan kemiskinan dari Pemerintah Pusat, meliputi : Program perlindungan sosial berbasis keluarga (BOS; PKH; RASKIN; BSM; JAMKESMAS; JAMPERSAL; BOK; BLSM; Program pemberdayaan masyarakat berbasis komunitas (PNPM Mandiri Perkotaan; PNPM Mandiri Perdesaan; PNPM Mandiri Infrastruktur Perdesaan; PNPM Mandiri usaha mina perdesaan; PNPM Mandiri pariwisata; PNPM Mandiri PUAP; PNPM Mandiri Integrasi); Program pemberdayaan ekonomi kerakyatan berbasis UMKM-K (KUR; CSR; KUBE); Program serba murah bagi masyarakat miskin dan pemberdayaan tenaga kerja/program serba murah (Rumah murah; angkutan murah; Rumah tidak layak huni).

Sedangkan Program penanggulangan kemiskinan Propinsi Banten, Meliputi : Program perlindungan sosial berbasis keluarga (Jamsosratu; Jamkesda; BOP Raskin); Program pemberdayaan masyarakat berbasis komunitas (program pembangunan perdesaan terpadu); Program pemberdayaan ekonomi kerakyatan berbasis UMKM-K (KUBE; KUBE JAMSOSRATU; JAMKRIDA); Program serba murah bagi masyarakat miskin dan pemberdayaan tenaga kerja/program serba murah (Kampung merah putih; Bedah kampung; Listrik desa; RTLH).

\begin{tabular}{lcr} 
Beberapa & program & \multicolumn{2}{c}{ Penanggulangan } \\
kemiskinan & oleh & $\begin{array}{c}\text { Pemerintah Kota } \\
\text { Tangerang }\end{array}$ yang sudah dilaksanakan
\end{tabular}

diantaranya : Program perlindungan sosial berbasis keluarga (Tangerang cerdas; Program simpanan keluarga sejahtera; Multiguna/BPJS; Fasilitasi distribusi raskin); Program pemberdayaan masyarakat berbasis komunitas (Program Tangerang berbenah; Program Tangerang bersih); Program pemberdayaan ekonomi kerakyatan berbasis UMKM-K (KUBE; Progam pengembangan sistem pendukung usaha bagi UMKM; Fasilitasi peningkatan kemitraan usaha bagi UMKM); Program serba murah bagi masyarakat miskin dan pemberdayaan tenaga kerja (Rumah tidak layak huni; Angkutan murah; Air minum untuk masyarakat berpenghasilan rendah). Sedangkan strategi yang dijalankan oleh Pemerintah Kota Tangerang untuk mengimplementasikan kebijakan sesuai Perda Nomor 7 Tahun 2012 antara lain:

1. Strategi perlindungan sosial dengan tujuan untuk memberi jaminan rasa aman dan perlindungan yang disebabkan karena dampak negatif krisis ekonomi, dan peningkatan beban pengeluaran penduduk dan keluarga miskin;

2. Strategi perluasan kesempatan pemenuhan hak dasar dengan maksud untuk menciptakan kondisi lingkungan ekonomi, politik, dan sosial yang memungkinkan penduduk dan keluarga miskin memperoleh kesempatan yang seluas-luasnya dalam pemenuhan hakhak dan peningkatan taraf hidupnya secara berkelanjutan;

3. Strategi peningkatan kapasitas sumber daya ekonomi dengan memberikan kesempatan kepada penduduk dan keluarga miskin untuk mengembangkan potensi dan kemampuan ekonominya; 
4. Strategi pemberdayaan masyarakat dengan maksud untuk meningkatkan peran serta kelembagaan yang ada di masyarakat serta memperluas partisipasi penduduk dan keluarga miskin dalam pengambilan keputusan kebijakan publik yang menjamin penghormatan,

\section{Penutup}

Keijakan dan strategi pengentasan kemiskinan yang dijalankan oleh Pemerintah Kota Tangerang selama periode 2011-2014 menuai hasil baik dimana jumlah penduduk miskin menurut data BPS Kota Tangerang Dalam Angka Tahun 2015 mulai dari tahun 2011 sampai dengan 2014 memperlihatkan adanya penurunan persentase penduduk miskin secara berurut dari tahun 2011, 2012, 2013, 2014 adalah sebesar $6,14 \% ; 5,55 \% ; 5,04 \% ; 4,91 \%$, atau jumlah penduduk miskin berkurang dari tahun 2012-2014 sebagai berikut secara berurutan 107.000, 103.071, 98.763 jiwa. Ini menggambarkan bahwa adanya sinergi antara aktor-aktor pelaku dan pihak-pihak yang bertanggungjawab dalam menjalankan kebijakan dan strategi pengentasan kemiskinan. Naiknya angka Indeks

\section{DAFTAR PUSTAKA}

Frank, Robert H, (1991). Microeconomics and Behaviour, Third edition, The Mc Graw Hill Companies Inc. USA.

Madani, Muhlis. (2011) Dimensi Interaksi Aktor Dalam Proses Perumusan Kebijakan Publik. Yogyakarta : Graha Ilmu.

Master Plan Penganggulangan Kemiskinan Kota Tangerang 2014-2018

Miles, Matthew B. dan A. Michael Huberman. Analisis Data Kualitatif, Perjemah Tjetjep Rohendi Rohidi, Pendamping Mulyarto. Jakarta: Penerbit Universitas Indonesia ( UI Press), 1992.

Nurwidiastuti, (2001). Kemiskinan : Telaah Kritis dan Alternatif Penanggulangannya,Kajian Bisnis, 24 September-Desember 2001, STIE Widya Wiwaha.

Prathama Rahardja dan Mandala Manurung, Pengantar Ilmu Ekonomi, Ed 3. Lembaga Penerbit UI. 2008 perlindungan, dan pemenuhan hak-hak dasar; dan

5. Strategi kemitraan dengan maksud untuk mengembangkan hubungan kerja sama lokal, regional, nasional, dan internasional dalam upaya penanganan dan penanggulangan masalah kemiskinan

Pembangunan Manusia (IPM) secara berurutan dari tahun 2011, 2012, 2013 adalah 75,72., 76,06, dan 75,87 serta Angka Harapan Hidup dari Tahun 2011, 2012, dan 2013 adalah 68,44., 68,56., dan 71,09. Peningkatan IPM dan Angka Harapan Hidup ini menunjukkan adanya peningkatan hasil target sasaran sektoral kebijakan dan strategi pengentasan kemiskinan. Secara umum penelitian ini menemukan bahwa kebijakan dan strategi pengentasan kemiskinan di Kota Tangerang baik kebijakan vertikal maupun koordinasi hubungan antaran SKPD dalam pengentasan kemiskinan sudah berjalan cukup baik dan perlu ditingkatkan agar percepatan pengentasan kemiskinan bisa dicapai sesuai dengan Master Plan Pengentasan Kemiskinan Kota Tangerang 2014-2018.

Subarsono, AG. (2005) Analisis Kebijakan Publik : Konsep, Teori dan Aplikasi. Yogyakarta: Pustaka Pelajar.

Surbakti, Ramlan. (2010) Memahami Ilmu Politik. Surabaya : Grasindo.

Suyanto, B. 1995, Perangkap Kemiskinan: Problem Strategi Pengentasannya. Surabaya. Airlangga University Press.

Suyanto, Bagong dan Karnaji. (2005) Kemiskinan dan Kesenjangan Sosial: ketika pembangunan tak berpihak kepada rakyat miskin. Surabaya: Airlangga University Press.

Terianus. 2014. Implementasi Kebijakan Publik: Review Teori. Jurnal Ilmu Sosial, Volume 12. 1 April 2014

Undang-Undang Nomor 25 Tahun 2000 tentang PROPENAS 
Wahab, Solichin Abdul. (2008) Pengantar Analisis Kebijakan Publik. Malang : UPT Penerbitan Universitas Muhammadiyah Malang.

Widodo, ST, (1990), Indikator Ekonomi: Dasar Perhitungan
Perekonomian Indonesia, Kanisius, Jakarta

World Bank, 2012. Social Assistance

Program and Public

Expenditure Review 2005- 2010. 